\title{
Determinants of Customer Satisfaction on Service Quality: A Study of Railway Platforms in India
}

\author{
Geetika, Shefali Nandan \\ Motilal Nehru National Institute of Technology
}

\begin{abstract}
Service quality has been viewed as a determinant of customer satisfaction. Different dimensions of service quality have been considered by various researchers. This study identifies components of service quality of Indian Railways at railway platforms. The study is exploratory in nature and uses factor analysis to identify the most important factors of customer satisfaction with service quality. The research methodology is empirical, and a survey of passengers (customers) was conducted. The findings reveal that five factors are considered important for determining satisfaction with railway platforms, the most important of which are refreshments and behavioral factors. Managerial and theoretical implications are drawn and discussed in the paper, and a model is proposed.
\end{abstract}

\section{Introduction}

Satisfaction from service quality is usually evaluated in terms of technical quality and functional quality (Gronroos 1984). Usually, customers do not have much information about the technical aspects of a service; therefore, functional quality becomes the major factor from which to form perceptions of service quality 
(Donabedian 1980, 1982). Service quality may be defined as customer perception of how well a service meets or exceeds their expectations (Czepiel 1990). Service quality can be measured in terms of customer perception, customer expectation, customer satisfaction, and customer attitude (Sachdev and Verma 2004). Ekinci (2003) indicates that the evaluation of service quality leads to customer satisfaction. Rust and Oliver (1994) define satisfaction as the "customer fulfillment response," which is an evaluation as well as an emotion-based response to a service. This paper is an attempt to put forth the role of service quality in affecting customer satisfaction in the context of railway services, with special reference to platforms in the North Central Zone of Indian Railways.

\section{Literature Review}

Various scholars have considered different dimensions of service quality. Gronoos (1884) considers technical, functional, and reputational quality; Lehtinen and Lehtinen (1982) consider interactive, physical, and corporate quality; and Hedvall and Paltschik (1989) focus on willingness and ability to serve and the physical and psychological access to the service. In conceptualizing the basic service quality model, Parasuraman et al. (1985) identified 10 key determinants of service quality as perceived by the service provider and the consumer, namely, reliability, responsiveness, competence, access, courtesy, communication, credibility, security, understanding/ knowing the customer, and tangibility to formulate a service quality framework, SERVQUAL. Later (in 1988), they modified the framework to five determinants: reliability, assurance, tangibles, empathy, and responsiveness, or RATER. The techniques of customer satisfaction analysis allow the critical aspects of the supplied services to be identified and customer satisfaction to be increased (Cuomo 2000).

Table 1 summarizes the findings in the literature consulted to understand various determinants of basic service quality.

Table 1. Determinants of Quality

\begin{tabular}{|l|l|}
\hline Quality Determinants & Authors \\
\hline Technical aspects, functional aspects & Gronroos $(1984)$ \\
\hline Functional aspects & $\begin{array}{l}\text { Donabedian }(1982,1980) \\
\text { Gronroos }(1984)\end{array}$ \\
\hline Customer perception, customer expectation & $\begin{array}{l}\text { Czepiel }(1990) \\
\text { Sachdev and Verma (2004) } \\
\text { TCRP Report 100 }\end{array}$ \\
\hline Customer expectation, customer satisfaction and customer attitude & Sachdev and Verma (2004) \\
\hline
\end{tabular}


The literature review also shows that researchers have identified different factors of quality in the context of different services. Transit Cooperative Research Plan (TCRP) Report 100 (Chapter 2) defines transit quality as "the overall measured or perceived performance of transit service from the passenger's point of view." TCRP Report 88 (TCRP Report 100, Chapter 2) defines five categories of measures that wholly or partially reflect the passenger's point-of-view in transit services: (1) availability of transit service, (2) service monitoring, (3) travel time, (4) safety and security, and (5) maintenance and construction activity on passenger trips. Vanniarajan and Stephen (2008) identified the attributes that passengers use to evaluate the service quality of Indian Railways as reliability, assurance, empathy, tangibles, and responsiveness. It was found that passengers were "moderately satisfied" to "satisfied" on these dimensions. Agrawal (2008) identified employee behavior as most important determinant of customer (passenger) satisfaction with Indian Railway services.

Eboli and Mazzulla (2007) measured customer satisfaction in the context of bus service on various factors including availability of shelter and benches at bus stops, cleanliness, overcrowding, information system, safety, personnel security, helpfulness of personnel, and physical condition of bus stops. TCRP Report 100 identifies the following elements at bus stations for efficient service: shelters, waiting rooms and seating, doorways, stairways, escalators, signage and information displays, public address systems, and passenger amenities (including shelters, benches, vending machines, trash receptacles, lighting, phone booths, art, and landscaping).

In a study on Internet banking, consumers gave the highest weight to the quality of service while selecting a particular bank (Geetika et al. 2008). In another study of customer satisfaction with banking services, factors of customer satisfaction were traditional (basic) facilities, convenience, behavior of employees, and the environment of bank (Jham and Khan 2008).

J. D. Power and Associates (2008a) measured overall customer satisfaction of electric utilities through six factors: power quality and reliability, customer service, company image, billing and payment, price, and communications. J. D. Power and Associates (2008b) also measured customer satisfaction with high-speed and dialup Internet service providers based on five factors: performance and reliability, cost of service, customer service, billing, and offerings and promotions. In another study, J. D. Power and Associates (2008c) found communication (information systems) to be a determinant of customer satisfaction for customers of utility companies. 
Ribiere et al. (1999) identified customer satisfaction with hospital information systems in terms of timeliness, accuracy, and completeness. Yet another study on satisfaction with hospital services included communication with patients, competence of staff, staff demeanor, quality of the facilities, and perceived costs (Andaleeb 1998).

Customer satisfaction with full-service moving companies was measured across seven factors: transportation of belongings, loading service, unloading service, optional coverage, estimate process, packing service, and insurance/damage claims. This implies that the quality of basic facilities and other supporting facilities were used as criteria for satisfaction (J. D. Power and Associates Reports 2007).

A study on customer satisfaction from consultant services identified various factors including perceived competence of the consultant and the attitude of consultants toward the customer during the service production process (Sonne 1999).

Table 2 provides a summary of research on attributes of service quality leading to consumer satisfaction in the context of various services. The heterogeneous service contexts are taken for developing a sound theoretical base for the present research and for identifying major common attributes of service quality irrespective of the context as well as within the context.

\section{Case Study of Indian Railways (North Central Zone)}

Indian Railways is the largest rail network in Asia and the world's second largest under one management. It is a multi-gauge, multi-traction system covering 108,706 kilometers, with 6,853 stations across the length and breadth of the country. It runs 11,000 trains, of which 7,000 are passenger trains that carry 13 million passengers every day. It is the largest employer in the organized sector in India, with a workforce of 1.54 million. (www.indianrailway.gov.in).

For administrative purposes, Indian Railways is divided into 17 zones. The North Central Railway (NCR) is one of the 17 railway zones in India. In its present form, NCR came into existence on April 1, 2003, and comprises the reorganized Allahabad Division of Northern Railway, the Jhansi Division of Central Railway, and the new Agra Division. It is headquartered at Allahabad (Uttar Pradesh), and its network extends over a large area of North Central India, covering the states of Uttar Pradesh, Madhya Pradesh, Rajasthan, and Haryana. 
Table 2. Literature Review Summary on Customer Satisfaction

\begin{tabular}{|c|c|c|}
\hline Sector & $\begin{array}{l}\text { Factors Identified/Considered for } \\
\text { Customer Satisfaction }\end{array}$ & Authors \\
\hline \multirow[t]{3}{*}{ Railways } & $\begin{array}{l}\text { Reliability, assurance, empathy, tangibles, and } \\
\text { responsiveness }\end{array}$ & $\begin{array}{l}\text { Vanniarajan and Stephen } \\
\text { (2008) }\end{array}$ \\
\hline & Employee behavior and other factors & Agrawal (2008) \\
\hline & $\begin{array}{l}\text { Availability of transit service, service monitor- } \\
\text { ing, travel time, safety and security, mainte- } \\
\text { nance and construction }\end{array}$ & TCRP Report 88, 100 \\
\hline Bus transportation & $\begin{array}{l}\text { Availability of shelter and benches at bus } \\
\text { stops, cleanliness, overcrowding, information } \\
\text { system, safety, personnel security, helpfulness } \\
\text { of personnel, physical condition of bus stops }\end{array}$ & $\begin{array}{l}\text { Eboli and Mazzulla } \\
(2007) \\
\text { TCRP Report } 100\end{array}$ \\
\hline Tourism & Service quality & Ekinci (2003) \\
\hline $\begin{array}{l}\text { Full-service moving } \\
\text { companies }\end{array}$ & $\begin{array}{l}\text { Transportation of belongings, loading service, } \\
\text { unloading service, optional coverage, estimate } \\
\text { process, packing service, insurance/dam- } \\
\text { age claims (basic facilities, other supporting } \\
\text { facilities) }\end{array}$ & $\begin{array}{l}\text { J.D. Power and Associates } \\
\text { Reports (2007) }\end{array}$ \\
\hline $\begin{array}{l}\text { Gas and Electricity } \\
\text { Suppliers }\end{array}$ & $\begin{array}{l}\text { Power quality and reliability, customer } \\
\text { service, company image, billing and payment, } \\
\text { price, communications, information system }\end{array}$ & $\begin{array}{l}\text { J.D. Power and Associates } \\
\text { Reports (2008a, 2008c) }\end{array}$ \\
\hline $\begin{array}{l}\text { Internet Service } \\
\text { Provider (ISP) }\end{array}$ & $\begin{array}{l}\text { Performance and reliability, cost of service, } \\
\text { customer service, billing, offerings and pro- } \\
\text { motions }\end{array}$ & $\begin{array}{l}\text { J.D. Power and Associates } \\
\text { (2008b) }\end{array}$ \\
\hline \multirow[t]{2}{*}{ Banking } & Service quality & Geetika et al. (2008) \\
\hline & $\begin{array}{l}\text { Basic facilities, convenience, behavior of } \\
\text { employees, general environment }\end{array}$ & Jham and Khan (2008) \\
\hline Consultancy & Behavior of employees, service quality & Sonne (1999) \\
\hline \multirow[t]{2}{*}{ Health Care } & $\begin{array}{l}\text { Information system in terms of timeliness, } \\
\text { accuracy and completeness }\end{array}$ & Ribiere et al. (1999) \\
\hline & $\begin{array}{l}\text { Communication with patients (information } \\
\text { system), competence of staff, staff demeanor } \\
\text { (behavior), quality of facilities, perceived costs }\end{array}$ & Andaleeb (1998) \\
\hline
\end{tabular}

Indian Railways is the major mode of transport in the country for passengers as well as freight due to its large network, number of trains, and affordability. On the industry front, it is the only player; hence, a monopoly has been created (which is legal). On the market front, the majority of its customers are illiterate/semieducated and low/middle income with no/low consciousness for quality aspects 
of service. According to the 2001 census survey in India, the effective literacy rate in India was 65.4 percent, so about one-third of the population is illiterate. As many as 260 million persons live below the poverty line. Railways provide them with a convenient, accessible, and affordable mode of transportation. The monopoly structure has created a typical situation where the service provider (Indian Railways) has no competition and can afford to ignore aspects such as quality of service, customer satisfaction, and product promotion. The railway is the lifeline of Indian economy and society, but it is far from healthy and satisfactory. The focus of this paper is to study and analyze the managerial aspects of services rather than to study the technical and engineering aspects of the railway.

For the purpose of analysis, the services of Indian Railways can be divided into three broad categories: ticketing, on-board services, and facilities at platforms. Tandon (2006) observes that improvements have been effected by Indian Railways to minimize ticket dispensing time through modernized passenger reservation systems using computers and the Internet at a large number of stations. He further highlights that the passengers also want efficiency, effectiveness, and politeness in service. Sharma (2006) asserts that railway enquiry counters play a pivotal role in customer satisfaction, but railway enquiry service is far from satisfactory in India. TCRP Report 100 (Chapter 7) identifies the following elements at railway stations for determining quality: space per passenger (crowding), facilities for disabled persons (ramps etc.), facilities for evacuation, security (including presence of law enforcement personnel, video cameras, and emergency call boxes), visibility, lighting, and clarity of station layout and way-finding.

Scholars have undertaken studies on various aspects of railway services, but platforms have failed to attract researcher attention. Railway platforms are an important part of the railway system. Waiting at a platform may range from 15 minutes to several hours (especially in the Indian context, where late running of trains is normal) to wait for a connecting train or due to late running of a train. A case was filed against Indian Railways highlighting the agony faced by the senior citizens and children due to delays in the arrival of trains (http://www.igovernment.in/site/ Railways-pulled-to-court-for-running-trains-late/?section=Human\%20Rights/).

There are various angles to this situation, but in this paper the premise is that passengers necessarily have to use platform services, and their agony may be mitigated by making their stay at the platforms more comfortable. Hence, a study has been attempted to determine customer (passenger) perceptions of satisfactory service quality at railway platforms. 


\section{Research Design}

This research is diagnostic in nature and uses a case study method for fulfilling research objectives. The literature review clearly indicates that different variables would be important for different services for customer satisfaction. It is further seen that a study on the service quality of railway platforms and level of customer satisfaction from this service has been neglected by researchers in the Indian context. Hence, an attempt is made to study customer perception of quality of service in the context of railway platforms. A case study method is adopted and supplemented with findings of a small survey to identify the determinants of customer satisfaction with this very important public utility in the special context of India.

\section{Objectives}

The study aims to identify the factors for passenger satisfaction regarding facilities provided on platforms. Customer satisfaction has been commonly accepted as an indicator of service quality (Geetika et al. 2008; Sachdev and Verma 2004; Ekinci 2003; Czepiel 1990). However, the literature shows that there is no consensus on the determinants of service quality. Therefore, the basic objective of the study is to identify important factors determining service quality of Indian Railways platforms that lead to customer satisfaction.

\section{Sampling and Survey}

The universe in this case is defined as the entire population of the country and foreign nationals visiting India. Hence, a definite, statistically-sound sample was not feasible. Convenience sampling was used for the purpose of the survey, and a research sample was taken to measure customer perception. The survey was carried out on different days at railway platforms at Allahabad Junction. Allahabad Junction is significant for two reasons; first, it is the headquarters of the North Central Railway (NCR) and second, all trains covered under NCR pass through Allahabad Junction, along with large number of trains of Central Railway, North Eastern Railway, and other zones. There are 12 platforms at the Allahabad railway station. A team of $20 \mathrm{MBA}$ students visited these platforms on different days during different hours of the day with the objective to cover passengers from all probable trains. A total of 700 passengers were contacted. This was simply a research sample and may not truly represent the entire user population; however, the test of significance has been done and shows that the sample size would not affect the results. 


\section{Research Instrument}

Since the literature depicted that determinants vary with services, it was determined inadvisable to use any of the existing instruments. This made our task difficult but necessary for achieving the research objectives. An instrument was developed on the basis of the existing literature, observations, the pilot study, and expert opinion. The attributes related to service quality of Indian Railways-passenger satisfaction and passenger perception-were generated with the help of reviews and exploratory study. Interviews were conducted with passengers who travel frequently to identify the attributes for passenger (customer) satisfaction. These preliminary surveys and reviews were used to generate general variables for passenger satisfaction on railway platforms. These variables were supported with the help of the literature review. These were further refined to form a questionnaire.

The questionnaire included 16 variables to measure customer (passenger) satisfaction from service quality, including:

1. sufficiency of seating space

2. lighting

3. fans

4. drinking water and sanitation

5. clarity of announcements

6. accuracy of announcements

7. frequency of announcements

8. reservation chart display

9. affordability of refreshments

10. quality of refreshments

11. quantity of refreshments

12. security of self

13. security of luggage

14. behavior of porters

15. behavior of railway staff

16. management of parking

A fiv- point Likert scale ranging from "least satisfied" to "most satisfied" was used to measure user satisfaction level. A Likert scale was used because it allowed the 
researchers to quantify opinion-based items, and a scale with balanced keying (an equal number of positive and negative statements) could obviate the problem of acquiescence bias.

\section{Analysis and Data Interpretation}

Nhat and Hau (2007) identified the determinants of retail service quality using factor analysis. The same tool was used by Hsu et al. (www.academic-papers.org) and Agrawal (2008) to identify determinants of customer satisfaction on Internet shopping. The same method was used here to identify the factors determining customer (passenger) satisfaction. Factor analysis was done to identify the factors determining passenger satisfaction on railway platforms and to test the hypothesis formulated regarding the factors determining passenger satisfaction. Data were analyzed using SPSS 11.5 software.

The passengers were asked to rate the 16 variables on a five-point scale according to their experience. The test of validity of data was examined with the help of a KaiserMeyer-Ohlin (KMO) measure of sample adequacy and Barlett's test of sphericity. These two tests satisfied the validity of data for factor analysis (Table 3).

Table 3. Kaiser-Meyer-Ohlin Measure and Bartlett's Test

\begin{tabular}{|l|c|c|}
\hline \multirow{2}{*}{ KMO Measure of Sampling Adequacy } & \multicolumn{2}{|c|}{.793} \\
\hline \multirow{2}{*}{ Bartlett's Test of Sphericity } & Approx. Chi-Square & 1621.146 \\
\cline { 2 - 3 } & $\mathrm{df}$ & 120 \\
\cline { 2 - 3 } & Sig. & .000 \\
\hline
\end{tabular}

To determine the number of components, only the eigen values greater than or equal to 1 were considered (Guttman 1954; Kaiser 1960). In addition, the KMO measure and the Barlett Sphericity test were effected (Fabbris 1997). The extraction method was Principal Axis Factoring; the rotation method was Oblimin with Kaiser Normalization.

The factor analysis resulted in five factors-refreshments, behavior, information system efficiency, basic facilities, and security. These five factors were found to have eigen values greater than 1 and, hence, are significant. The reliability coefficients of these factors range from 0.6 to 0.8 . The factor loading of the variables determining satisfaction in each factor, the reliability coefficient (Cronbach alpha), the eigen value, and the percent of variation explained by the factors are 
shown in Table 3. The most important factor determining satisfaction on railway platforms was found to be "refreshments," since the eigen value and percent of variation explained by this factor are 4.866 and 30.412, respectively. This factor consists of three variables with a reliability coefficient of 0.8627 . It shows that the included variables explain this factor to the extent of 86.27 . The percent variation explained by this factor is 30.4 percent.

The next two factors identified are "behavior towards passengers" and "information system efficiency." Their respective eigen values are 1.702 and 1.482. Each of these factors consists of three variables, with reliability coefficients of 0.7037 and 0.8407 each. The percent variations explained by these factors are 10.638 and 9.260 , respectively.

The other two factors determining passenger satisfaction on railway platforms as identified by factor analysis are "basic facilities" and "security," with four and two variables each, respectively, and with reliability coefficients of 0.6046 and 0.8200 , respectively. The percent variation explained by these factors is 8.454 and 6.425 , respectively. Table 4 shows the correlation among various factors.

\section{Table 4. Factor Loading of Variables}

\begin{tabular}{|c|c|c|c|c|c|}
\hline Factor & Variable & $\begin{array}{c}\text { Factor } \\
\text { Loading }\end{array}$ & $\begin{array}{l}\text { Reliability } \\
\text { Coefficient }\end{array}$ & $\begin{array}{l}\text { Eigen } \\
\text { Value }\end{array}$ & $\begin{array}{l}\text { Percent of } \\
\text { Variation } \\
\text { Explained }\end{array}$ \\
\hline Refreshments & $\begin{array}{l}\text { Refreshments affordability } \\
\text { Refreshments quality } \\
\text { Refreshments quantity }\end{array}$ & $\begin{array}{l}0.694 \\
0.884 \\
0.683\end{array}$ & $\begin{array}{l}0.8627 \\
0.7037\end{array}$ & $\begin{array}{l}4.866 \\
1.702\end{array}$ & $\begin{array}{l}30.412 \\
10.638\end{array}$ \\
\hline $\begin{array}{l}\text { Behavior } \\
\text { towards } \\
\text { passenger }\end{array}$ & $\begin{array}{l}\text { Behavior of railway staff } \\
\text { Behavior of porters } \\
\text { Management of parking }\end{array}$ & $\begin{array}{l}0.650 \\
0.785 \\
0.412 \\
\end{array}$ & 0.8407 & 1.482 & 9.260 \\
\hline $\begin{array}{l}\text { Information } \\
\text { system } \\
\text { efficiency }\end{array}$ & $\begin{array}{l}\text { Clarity of announcements } \\
\text { Accuracy of announcements } \\
\text { Frequency of announcements } \\
\text { Reservation chart display }\end{array}$ & $\begin{array}{c}0.72 \\
0.885 \\
0.725 \\
0.308\end{array}$ & 0.6046 & 1.353 & 8.454 \\
\hline Basic facilities & $\begin{array}{l}\text { Sufficiency of \# of benches } \\
\text { Lighting } \\
\text { Fans } \\
\text { Reservation chart display }\end{array}$ & $\begin{array}{l}0.637 \\
0.460 \\
0.561 \\
0.301\end{array}$ & 0.8200 & 1.028 & 6.425 \\
\hline Security & $\begin{array}{l}\text { Security of self } \\
\text { Security of luggage }\end{array}$ & $\begin{array}{l}0.713 \\
0.850\end{array}$ & 0.8200 & 1.028 & 6.425 \\
\hline
\end{tabular}


As evident from Table 4, there is a low correlation between different factors, the maximum being 0.466 (between the factors "behavior towards passengers" and "security"). This means that all the five factors are independent, which implies that they are measuring unrelated dimensions.

Table 5. Factor Correlation Matrix

\begin{tabular}{|l|c|c|c|c|c|}
\hline Factor & Refreshments & $\begin{array}{c}\text { Behavior } \\
\text { Towards } \\
\text { Passengers }\end{array}$ & $\begin{array}{c}\text { Information } \\
\text { System } \\
\text { Efficiency }\end{array}$ & $\begin{array}{c}\text { Basic } \\
\text { Facilities }\end{array}$ & Security \\
\hline Refreshments & 1.000 & .170 & .366 & .327 & .339 \\
\hline $\begin{array}{l}\text { Behavior towards } \\
\text { passengers }\end{array}$ & .170 & 1.000 & .318 & .323 & .466 \\
\hline $\begin{array}{l}\text { Information system } \\
\text { efficiency }\end{array}$ & .366 & .318 & 1.000 & .342 & .342 \\
\hline Basic facilities & .327 & .323 & .342 & 1.000 & .341 \\
\hline Security & .339 & .466 & .342 & .341 & 1.000 \\
\hline
\end{tabular}

Extraction Method: Principal Axis Factoring

Rotation Method: Oblimin with Kaiser Normalization

The results provide statistical evidence to support identified determinants of customer satisfaction as refreshments, safety and security, basic facilities, information system, and behavioral aspects of service quality.

1. Refreshments: This aspect includes the availability, quality, quantity and affordability of edibles available to passengers on railway platforms. Passengers consider refreshments as the most important aspect of satisfaction with service quality of Indian Railways.

2. Behavioral factors: This refers to the behavior of railway staff, porters, and parking staff outside the platform. These factors have been found to impact customer satisfaction (Sonne 1999; Agrawal 2008; Vanniarajan and Stephen 2008; Jham and Khan 2008). Behavioral factors are the second most important determinant of customer satisfaction.

3. Information system: This refers to announcements at the railway station, their accuracy, frequency and clarity, and reservation chart display. The information system has been identified as a determinant of customer satisfaction (Andaleeb 1998; Ribiere et al. 1999; Eboli and Mazzulla 2007; TCRP Report 100). Passengers consider the information system the third most important determinant of satisfaction with service quality. 
4. Basic facilities: Basic facilities consist of sitting space, fans, and lighting. Basic facilities pertaining to different sectors are important determinants of customer satisfaction (Eboli and Mazzulla 2007; J.D. Power and Associates Reports 2007; TCRP Report 100). Basic facilities are the fourth most important determinant of customer satisfaction.

5. Safety and security: This refers to the safety and security of luggage and self, which have been identified as determinants of customer satisfaction in the transportation sector (Eboli and Mazzulla 2007; TCRP Report 100). Safety and security is the last most important determinant of customer satisfaction.

\section{Customer Satisfaction Model}

On the basis of factor analysis, a model of customer (passenger) satisfaction on railway platforms is proposed in Figure 1. In the model, customer satisfaction is the dependent variable and refreshments, information system, safety and security, behavioral aspects, and basic facilities are the independent variable.

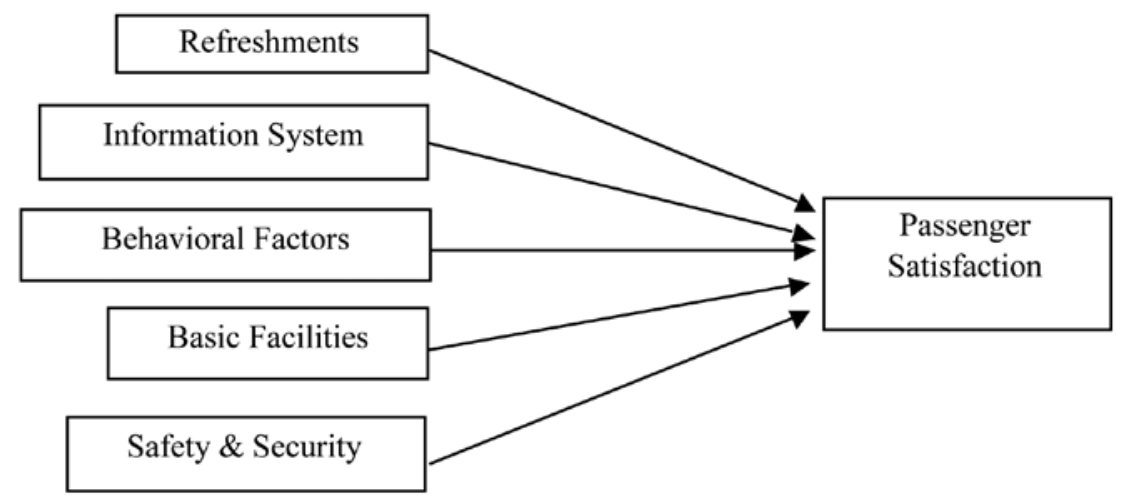

\section{Figure 1. Research Model for Determinants of Passenger Satisfaction on Railway Platforms}

This model has been derived on the basis of statistical evidence; hence, it is validated. It can be further used and developed for similar other researches. 


\section{Conclusions}

Although several studies have attempted to identify factors determining overall user satisfaction with Indian Railways, railway platforms have remained a neglected aspect.

The contribution of this study is the identification of factors that determine user satisfaction with the quality of services provided on railway platforms. The study is based on empirical research. Determinants identified are availability and quality of refreshments, effectiveness of information systems, behavior of railway staff, basic amenities provided on platforms, and safety and security. Refreshments and behavioral factors are considered most important by passengers. These factors determine passenger satisfaction on railway platforms and may be different from determinants of satisfaction with Indian Railways as a whole. The study thus provides a direction for railway administration whereby areas for improving services may be identified and user (passenger) satisfaction, specifically on railway platforms, may be enhanced.

\section{Managerial Implications}

This study has identified the actual determinants of customer satisfaction with quality of service provided on railway platforms. In this respect, this paper suggests certain policy implications for Indian Railways. The proposed model of customer satisfaction may be used as a basis to plan efforts towards increasing customer satisfaction. Availability of good quality and quantity of refreshments at affordable prices is the key factor impacting customer perception of service quality. It may be due to the fact that while waiting on the platform, refreshments may help the passengers mitigate some of their miseries. By improving these food-related aspects, railway administration may increase satisfaction among passengers. In addition, other factors that passengers consider important at railway platform are behavior of staff, porters, parking staff, and quality of the information system. This implies that railway staff must be trained in such a way that their "soft" skills are enhanced. Appropriate action plans may be taken to enhance basic facilities and improve security on platforms.

The model, although designed in a specific context, may be extended to other similar services and help improve quality of life for the masses and thus increase overall satisfaction. 


\section{References}

Andaleeb, S. S. 1998. Determinants of customer satisfaction with hospitals: A managerial model. International Journal of Health Care Quality Assurance 11(6): 181-187.

Agrawal, R. 2008. Public transportation and customer satisfaction. Global Business Review 9(2): 257-272.

Bolton, R. N., and J. H. Drew. 1991. A longitudinal analysis of the impact of service changes on customer attitude. Journal of Marketing 55 (January): 1-19.

Boulding, W., A. Kalra, S. Richard, and V. A. Zeitmal. 1993. A dynamic process model of service quality: From expectations to behavioural intentions. Journal of Marketing Research 30 (Feb): 7-27.

Buzzell, R. D., and B. T. Gale. 1987. The PIMS Principles. New York: Free Press.

Crosby, P. B. 1979. Quality is Free: The Art of Making Quality Certain. New York: American Library.

Cuomo, M. T. 2000. La customer satisfaction. Vantaggio competitivo e creazione divalore. Padova: CEDAM.

Czepiel, J. A. 1990. Service encounters and service relationships: Implications for research. Journal of Business Research 20: 13-21.

Donabedian, A. 1980. Explorations in Quality Assessment and Monitoring. Volume 1, The Definition of Quality and Approaches to Its Assessment. Ann Arbor, Michigan: Health Administration Press.

Eboli, L., and G. Mazzulla. 2007. Service quality attributes affecting customer satisfaction for bus transit. Journal of Public Transportation 10 (3): 21-34.

Ekinci, Y. 2003. An investigation of the determinants of customer satisfaction. Tourism Analysis 8(2): 193-196.

Geetika, N. Tanuj, and U. Ashwini. 2008. Internet banking in India: Issues and prospects. Journal of Bank Management VII(2): 47-61.

Gronroos, C. 1984. A service quality model and its marketing implications. European Journal of Marketing 18: 36-44. 
Hedvall, M. B., and M. Paltschik. 1989. An investigation in and generation of service quality concepts. In Marketing Thought and Practice in the 1990s, ed. Avlonitis, G.J. et al., European Journal of Marketing Academy, Athens.

J. D. Power and Associates Reports. 2007. Global Van Lines, Mayflower Transit and Two Men and a Truck rank highest in customer satisfaction with full-service moving companies.

J. D. Power and Associates Reports. 2008a. Residential gas utility satisfaction, http://www.jdpower.com/corporate/utilities/

J. D. Power and Associates Reports. 2008b. Internet service provider (ISP) residential customer satisfaction study.

J. D. Power and Associates Reports. 2008c. Satisfaction of business customers with electric utilities continues to climb to a new high due to improvements in customer care.

Jham, V., and K. M. Khan. 2008. Determinants of performance in retail banking: Perspectives of customer satisfaction and relationship marketing. Singapore Management Review, p://findarticles.com/p/articles/mi_qa5321/is_200807/ ai_n27901656/.

Jung, Y. L. 2006. Assessment of employees' perceptions of service quality and satisfaction with e-business. Proceedings of the 2006 ACM SIGMIS CPR conference on computer personnel research, Forty four years of computer personnel research: achievements, challenges and the future: 236-243.

Lehtinen, J. R., and O. Lehtinen. 1982. Service quality: A study of quality dimensions. Unpublished working paper, Service Management Institute: Helsinki.

Mququ, M. H. 2006. A survey of customer satisfaction, expectations and perceptions as a measure of service quality in SANBS, http://eprints.ru.ac.za/488/.

Nguyen, D. D. N., and H. Le Nguyen. 2007. Determinants of retail service quality: A study of supermarkets in Vietnam. Science and Technology Development 10(08): 15-23.

Parasuraman, A., V. A. Zeithaml, and L. L. Berry. 1985. A conceptual model of service quality and its implications for future research. Journal of Marketing 49 (Fall): 41-50. 
Parasuraman, A., V. A. Zeithaml, and L. L. Berry. 1988. SERVQUAL: A multiple-item scale for measuring customer perceptions of service quality. Journal of Retailing 64 (Spring): 12-40.

Railways pulled to court for running trains late. 01 August 2009. http:// www.igovernment.in/site/Railways-pulled-to-court-for-running-trainslate/?section=Human\%20Rights/

Ribière, V., A. J. LaSalle, R. Khorramshahgol, and Y. Gousty. 1999. Hospital information systems quality: A customer satisfaction assessment tool. Thirty-Second Annual Hawaii International Conference on System Sciences 4: 4011.

Rust, R. T., and A. J. Zahorik. 1993. Customer satisfaction, customer retention and market share. Journal of Retailing 69(2): 193-215.

Rust, R. T., and R. C. Oliver. 1994. Service quality: Insights and managerial implications from the frontier. In Service Quality: New Directions in Theory and Practice, ed. Rust, R. T., and R. C. Oliver. London: Sage Publications.

Sharma, C. P. (2006). Customer care-Indian Railways. CTRAM, www.ctram.indianrail.gov.in/3rdCTRAMJOURNAL.

Sachdev, S. B., and Verma, H. V. 2004. Relative importance of service quality. Journal of Services Research 4(1): 93-116.

Sonne, A-M. 1999. Determinants of customer satisfaction with professional services: A study of consultant services, Økonomisk Fiskeriforskning, http:// www.fiskeriforskning.no/nofima/publikasjoner/konomisk_fiskeriforskning/ konomisk_fiskeriforskning_1999_02/determinants_of_customer_satisfaction_with_professional_services_a_study_of_consultants_services.

Tandon, R. K. The Art and Science of Customer Care, EDTT(F)/Railway Board.

TQM perspective for public satisfaction of services of Indian railways, http:// articles.industrialsoft.org/report/indian_rail.htm.

Transit Cooperative Research Program (TCRP). 2009. Report 100: Transit Capacity and Quality of Service Manual, 2nd Edition, Part 2: 7.

Transit Cooperative Research Program (TCRP). 2009). Report 100: Transit Capacity and Quality of Service Manual, 2nd Edition, Part 7: 7-48. 
Vanniarajan, T., and A. Stephen. 2008. Railqual and passenger satisfaction: An empirical study in southern railways. Asia Pacific Business Review IV(1), January-March: 64-75.

Ribière, V., A. J. LaSalle, R. Khorramshahgol, and Y. Gousty. 1999. Hospital information systems quality: A customer satisfaction assessment tool. Thirty-Second Annual Hawaii International Conference on System Sciences 4: 4011.

www. academic-papers.org/ocs2/session/Papers/Poster/837.doc, retrieved 20 April 2008

Zahoik, A.J., and R. T. Rust. 1992. Modeling the impact of service quality on profitability: A review. In Advances in Services Marketing and Management, ed. Swartz, T.A, D. E. Bowen, and S. W. Brown. Greenwich: Jai Press.

Zeithaml, Parasuraman, and Berry. 1990. Delivering Quality Service; Balancing Customer Perceptions and Expectations. Free Press.

\section{About the Authors}

GEeTIKA (geetika@mnnit.ac.in) is professor of strategy and chair of the School of Management Studies at the Motilal Nehru National Institute of Technology in Allahabad and has 20 years of teaching and research experience. She has guided six Ph.D. scholars and written five books and is a prolific writer who regularly publishes in national and international journals. She conducts Faculty Development Programmes and Management Development Programmes on a regular basis, has represented India at several international forums, and has just completed an international project on women entrepreneurs.

SHEFALI NANDAN (eshefali@rediffmail.com) is a member of the faculty of the School of Management Studies at the Motilal Nehru National Institute of Technology in Allahabad. She has eight years of teaching experience and five years of research experience and has a number of publications in national and international journals. Her areas of interest include organizational behavior, women's issues, and human resource development. She has been a resource person for training programs in several organizations including the police academy and worked on a recentlycompleted international project on women entrepreneurs. 